
mildew. Horticultura Brasileira 32: 69-73.

\title{
Obtaining resistant lettuce progenies to downy mildew
}

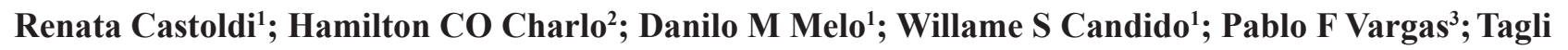 \\ Dalpian $^{4}$; Leila T Braz ${ }^{1}$ \\ ${ }^{1}$ UNESP-FCAV, Depto. Prod. Vegetal, Rod. Prof. Paulo Donato Castellane s/n, 14884-900 Jaboticabal-SP; rcastoldi@gmail.com; melo. \\ agro@hotmail.com; will_candido_ce@hotmail.com; leilatb@fcav.unesp.br ${ }^{2}$ IFTM, R. João Batista Ribeiro 4000, Mercês, 38064-790 \\ Uberaba-MG; hamiltoncharlo@iftm.edu.br; ${ }^{3}$ UNESP, R. Nelson Brihi Badur 430, Vila Tupy, Registro-SP; pablo@registro.unesp.br; \\ ${ }^{4}$ CATI, Casa da Agricultura de Ibirá, Av. Gabriel Sanches 725, 15860-000 Ibirá-SP; tagli.dalpian@cati.sp.gov.br
}

\begin{abstract}
Lettuce is the most consumed leafy vegetable in Brazil. Its production, nonetheless, is increasing in difficulties mainly due to the infestation of producing areas with Bremia lactucae. Thus, the use of horizontal resistant cultivars is the most viable alternative in controlling progress of disease. So, the objective of this study was to obtain resistant lettuce progenies to the races of downy mildew: SPB1:01, SPB1:02, SPB1:03, SPB1:04, SPB1:05, SPB1:06 and SPB1:07. The breeding consisted of two stages: crossover of parentals to obtain the resistant lettuce progenies and endurance test of the progeny to $B$. lactucae races. The parentals used to obtain progenies with resistance factor R-18 and R-38 were: JAB 4-13-7 and JAB 4-13-7. The Pedigree method was used for obtaining the progeny, using as default selections the Hortência cultivar and JAB 4-13-7genotype. After selection and selfing of the plants in the field, the resistance or susceptibility test was realized, by inoculation of the progenies from the crosses, with mixture of distilled water + sporangia of $B$. lactucae races SPB1:01, SPB1:02, SPB1:03, SPB1:04, SPB1:05, SPB1:06 and SPB1:07 obtained from isolates collected in the years 2008-2010. Fifteen days after inoculation, the seedlings were selected as resistant or susceptible, discarding those presenting sporulation and necrotic spots caused by B. lactucae. Through the Pedigree method we found 69 progenies $\mathrm{F}_{3}$ with good agronomic characteristics. However, after resistance or susceptibility test, only 19 showed all the plants resistant to downy mildew.
\end{abstract}

Keywords: Lactuca sativa, resistance factor, Bremia lactucae.

\begin{abstract}
RESUMO
Obtenção de progênies de alface crespa resistentes ao míldio

A alface é a hortaliça folhosa mais consumida no Brasil. No entanto, a dificuldade em produzi-la vem aumentando, principalmente pela infestação das áreas de produção por Bremia lactucae, sendo o uso de cultivares com resistência horizontal, a alternativa mais viável no controle da doença. Diante do exposto, o objetivo do presente trabalho foi obter progênies de alface crespa resistentes às raças de míldio SPB1:01, SPB1:02, SPB1:03, SPB1:04, SPB1:05, SPB1:06 e SPB1:07. O trabalho de melhoramento consistiu de duas etapas: cruzamento dos parentais para obtenção das progênies de alface crespa resistentes e teste de resistência das progênies às raças de B. lactucae. Os parentais utilizados na obtenção das progênies resistentes foram Argeles e linhagem JAB 4-13-7, visando a obtenção de progênies de alface do tipo crespa, com os fatores de resistência R-18 e R-38. Para tanto, adotou-se o método genealógico, tendo como padrão, para as seleções, a cultivar Hortência e o genótipo JAB 4-13-7. Após a seleção e autofecundação das plantas no campo, efetuou-se o teste de resistência ou suscetibilidade, por meio da inoculação nas progênies oriundas dos cruzamentos, de uma mistura de água destilada + esporângios de B. lactucae das raças SPB1:01, SPB1:02, SPB1:03, SPB1:04, SPB1:05, SPB1:06 e SPB1:07 obtidas de isolados coletados nos anos de 2008 a 2010. Quinze dias após a inoculação, as plântulas foram selecionadas, descartando aquelas que possuíam esporulação e pontos necróticos causados por $B$. lactucae. Pelo método genealógico, selecionaram-se 69 progênies $\mathrm{F}_{3}$ com boas características agronômicas. No entanto, após o teste de resistência ou suscetibilidade, somente 19 apresentaram todas as plantas resistentes ao míldio.
\end{abstract}

Palavras-chave: Lactuca sativa, fatores de resistência, Bremia lactucae.

\section{(Recebido para publicação em 30 de abril de 2013; aceito em 1 de novembro de 2013) (Received on April 30, 2013; accepted on November 1, 2013)}

$\mathrm{T}_{\mathrm{t}}^{\mathrm{h}}$ he lettuce (Lactuca sativa) is one of the most important vegetable crops grown worldwide, both in volume and value traded, presenting great consumer acceptance (Vieira \& Barreto, 2006), mainly because it is a good source of vitamins $\left(\mathrm{A}_{1}, \mathrm{~B}_{1}, \mathrm{~B}_{2}, \mathrm{~B}_{5}\right.$ and $\left.\mathrm{C}\right)$ and minerals ( $\mathrm{Ca}, \mathrm{Fe}, \mathrm{Mg}, \mathrm{P}, \mathrm{K}$ and $\mathrm{Na}$ ), besides showing reduced caloric content (Menezes et al., 2001). However, many pathogens limit the production in Brazil and in the world, among these pathogen, the Bremia lactucae, etiologic agent of downy mildew of lettuce.

The downy mildew is particularly important in environmental conditions of high humidity and mild to low temperature, causing significant economic losses to producers (Lebeda et al., 2001). According to $\mathrm{Su}$ et al. (2004), the optimum temperature for maximum sporulation of $B$. lactucae occurs at $15^{\circ} \mathrm{C}$.

Theoretically, the rate of the disease progression can be reduced by the use of various control procedures, such as management of irrigation shift, in order not to prolong the duration of wetness and/or ideal frequency of application of fungicides. However, the most viable alternative is to develop resistant varieties, as it is the only economically sustainable and effective method of control (Beharav et al., 2006).

In lettuce, breeding programs aiming resistance to downy mildew, 
it is important to know the diversity of races of $B$. lactucae, and the gene that confers resistance to each of these races, for subsequent transfer of this gene to cultivars with good agronomic characteristics. For this, it is necessary to use cultivars named differentials, which, according to Van Ettekoven \& Van Der Arend (1999), are divided into four groups, assigning values from 1 to 32 to each cultivar, possessing each one a gene Dm (Downy mildew) or resistance factor $(\mathrm{R})$.

Physiological races are identified or differentiated by the reaction they cause in a selected group of hosts (Bueno et al., 2001).

The genetic control of resistance to downy mildew is due to a dominant gene $(\mathrm{Dm})$ and its recessive allele that confers susceptibility (dm) (Sala, 2011). According to Costa et al. (2003), the genes DM-17, DM-18, R-36, R-37, R-38 and R-40, confer resistance to downy mildew races found in Brazil so far.

The genetic interaction between Bremia lactucae and lettuce has been studied, and a gene-to-gene relationship has been demonstrated. Dominant resistance genes (Dm) correspond to dominant avirulence genes (Avr). The combination of gene Dm and a corresponding avirulence (Avr) gene results in an incompatible interaction, expressed as the host hypersensitivity (Bonnier et al., 1994).

According to Matiello et al. (1997), since the diseases have become a major threat to production fields, most breeding programs have devoted much time and resources in searching genotypes with high yield and high resistance in the field. In Brazil, unlike the United States and Europe, the resistance to lettuce downy mildew has not been a goal of the breeding programs. This is because, according to Plantum (2010), through the mutations of the phytopathogen, the combination of several existing genes in the same cultivar can be overcome. Thus, the breeding program for resistance to downy mildew in lettuce has to be continuous, with the incorporation of new genes as the new races show up.
The set of races of $B$. lactucae may differ in different countries, mainly because of the changes of environmental conditions and in the use of planted materials. As the most part of the lettuce cultivars planted in Brazil is imported, many of these cultivars, characterized as resistant to mildew, when grown under Brazilian conditions, may not present resistance to the phytopathogen, not ensuring, in this way, the Brazilian producer, the disease control in planting areas.

The resistance depends on the host genotype as well as the variant of the pathogen, both affected by the environment. Therefore, knowledge of the physiological races is a prerequisite for a rigorous and successful test in the processes of selection of resistant plants (Lima et al., 2005).

Given the above, this study aimed to obtain progenies of crisp-leaf lettuce resistant to races $\mathrm{SPB1}: 01$, SPBl:02, SPBl:03, SPBl:04, SPBl:05, $\mathrm{SPBl}: 06$ and SPBl:07, since they are the predominant races in the state of São Paulo (Souza et al., 2011).

\section{MATERIAL AND METHODS}

The breeding program consisted of two phases: Parental cross and test of resistance of progenies to races of $B$. lactucae.

The parental crosses used to obtain resistant progenies were: Argeles (differentiating cultivar of crisp lettuce group, with resistance factor R-38, which confers resistance to races SPB1:01, SPB1:02, SPB1:03, SPB1:04, SPB1:05, SPB1:06 and SPB1:07) and the progeny JAB 4-13-7 (developed by the UNESP-FCAV Breeding Program, belonging to crisp group, leaves of shiny medium green coloration, good precocity, medium tolerance to early bolting, good tolerance to tip burn and with resistance factor R-18, which confers resistance to races SPBl:01, SPB1:02, SPB1:03, SPBl:04, SPB1:05, SPB1:06 and SPB1:07). These parentals were picked up aiming to obtain crisp lettuce progenies, with resistance factors R-18 and R-38, which are able to confer greater durability to resistance of this plant, minimizing the problems of overcoming resistance, very common in the development of lettuce cultivars resistant to downy mildew.

In order to obtain progenies with resistance to the seven races of $B$. lactucae identified, so far, in the state of São Paulo, the genealogical method was used, considered as a standard for selections the cultivar Hortência [a cultivar of the crisp-leaf group, which presents a cycle of 55 to 60 days; big and uniform plants, adapted for growing throughout the year in conventional or hydroponic cultivation; with big leaves and good base of plant and, tolerant to early bolting and to tip burn (Hortec, 2011)]; as well as the JAB 4-13-7 strain.

The crosses and selections were carried out in a greenhouse, from 01/30/09 to $11 / 14 / 10$.

The seeding was performed on $01 / 3 / 09$, in expanded polystyrene trays with capacity for 288 cells, filled with substrate Plantmax ${ }^{\circledR}$ HA. The trays were placed under protected cultivation, arch type, with $15 \mathrm{~m}$ long, $7 \mathrm{~m}$ wide, $3 \mathrm{~m}$ ceiling height and a low density polyethylene cover with thickness of 150 microns. The irrigation was performed twice a day.

The transplant was performed 31 days after sowing, in greenhouse, when the plants presented 3 or 4 definitive leaves. The spacing used was $0.50 \times 1.00$ $\mathrm{m}$ for a better crop management and in order to perform the crossings. For this, the seedlings were removed from the tray and they were put in the definitive location, previously prepared, according to the conventional system (plowing and harrowing), limestoned, to raise the base saturation to $80 \%$, and fertilized five days before the transplant, according to the results of soil chemical analysis.

The planting fertilization consisted of $40 \mathrm{~kg} \mathrm{ha}^{-1} \mathrm{~N}, 50 \mathrm{~kg} \mathrm{ha}^{-1} \mathrm{~K}_{2} \mathrm{O}$ and $200 \mathrm{~kg} \mathrm{ha}^{-1} \mathrm{P}_{2} \mathrm{O}_{5}$. Three dressing fertilizations were performed. The first one was performed 10 days after the transplant, and the other ones at 10-day intervals, totaling $70 \mathrm{~kg} \mathrm{ha}^{-1} \mathrm{~N}$ (Trani et al., 1997). The drip irrigation system was used, with daily irrigation to keep the soil always moist and suitable for a better development of the crop. 
Table 1. Lettuce progenies, from the cross Argeles x JAB 4-13-7, resistant and susceptible to Bremia lactucae races: SPB1:01, SPB1:02, SPB1:03, SPB1:04, SPB1:05, SPB1:06 and SPB1:07 (progênies de alface crespa, oriundas do cruzamento entre Argeles x JAB 4-13-7, resistentes e suscetíveis às raças de Bremia lactucae: SPB1:01, SPB1:02, SPB1:03, SPB1:04, SPB1:05, SPB1:06 e SPB1:07). Jaboticabal, UNESP, 2011.

\begin{tabular}{|c|c|c|c|c|c|c|c|}
\hline Crossings & $\begin{array}{c}\text { Total of } \\
\text { evaluated } \\
\text { plantlets }\end{array}$ & $\begin{array}{c}\text { Plantlets } \\
\text { without necrotic } \\
\text { spots }(\%)\end{array}$ & $\begin{array}{c}\text { Plantlets } \\
\text { without } \\
\text { sporulation }(\%)\end{array}$ & Crossings & $\begin{array}{c}\text { Total of } \\
\text { evaluated } \\
\text { plantlets }\end{array}$ & $\begin{array}{c}\text { Plantlets } \\
\text { without necrotic } \\
\text { spots }(\%)\end{array}$ & $\begin{array}{c}\text { Plantlets } \\
\text { without } \\
\text { sporulation (\%) }\end{array}$ \\
\hline$(\mathrm{AxJAB}) 1-1$ & 20 & 70.0 & 92.5 & $(\mathrm{AxJAB}) 4-25$ & 20 & 0.0 & 100.0 \\
\hline$(\mathrm{AxJAB}) 1-2$ & 20 & 92.5 & 100.0 & $(\mathrm{AxJAB}) 4-26$ & 20 & 42.5 & 100.0 \\
\hline$(\mathrm{AxJAB}) 1-3$ & 20 & 65.0 & 100.0 & $(\mathrm{AxJAB}) 4-27$ & 20 & 0.0 & 100.0 \\
\hline$(\mathrm{AxJAB}) 2-1$ & 20 & 80.0 & 100.0 & $(\mathrm{AxJAB}) 4-28$ & 20 & 80.0 & 97.5 \\
\hline$(\mathrm{AxJAB}) 2-2$ & 20 & 100.0 & 55.0 & $(\mathrm{AxJAB}) 4-29$ & 20 & 75.0 & 100.0 \\
\hline$(\mathrm{AxJAB}) 2-3$ & 20 & 50.0 & 100.0 & $(\mathrm{AxJ} A B) 4-30$ & 20 & 0.0 & 100.0 \\
\hline$(\mathrm{AxJAB}) 3-2$ & 20 & 100.0 & 100.0 & $(\mathrm{AxJAB}) 4-31$ & 20 & 95.0 & 100.0 \\
\hline$(\mathrm{AxJAB}) 3-3$ & 20 & 87.5 & 100.0 & $(\mathrm{AxJAB}) 4-32$ & 20 & 30.0 & 100.0 \\
\hline$(\mathrm{AxJAB}) 3-4$ & 20 & 100.0 & 100.0 & $(\mathrm{AxJAB}) 4-33$ & 20 & 0.0 & 100.0 \\
\hline$(\mathrm{AxJAB}) 4-1$ & 20 & 75.0 & 100.0 & $(\mathrm{AxJAB}) 4-34$ & 20 & 80.0 & 100.0 \\
\hline$(\mathrm{AxJAB}) 4-2$ & 20 & 90.0 & 100.0 & $(\mathrm{AxJAB}) 4-35$ & 20 & 87.5 & 100.0 \\
\hline$(\mathrm{AxJAB}) 4-3$ & 20 & 95.0 & 100.0 & $(\mathrm{AxJAB}) 4-36$ & 20 & 55.0 & 100.0 \\
\hline$(\mathrm{AxJAB}) 4-4$ & 20 & 52.5 & 100.0 & $(\mathrm{AxJAB}) 4-37$ & 20 & 82.5 & 100.0 \\
\hline$(\mathrm{AxJAB}) 4-5$ & 20 & 95.0 & 100.0 & $(\mathrm{AxJAB}) 4-38$ & 20 & 82.5 & 100.0 \\
\hline$(\mathrm{AxJAB}) 4-6$ & 20 & 90.0 & 100.0 & $(\mathrm{AxJ} A B)$ 4-39 & 20 & 70.0 & 100.0 \\
\hline$(\mathrm{AxJAB}) 4-7$ & 20 & 40.0 & 100.0 & $(\mathrm{AxJAB}) 4-40$ & 20 & 80.0 & 100.0 \\
\hline$(\mathrm{AxJAB}) 4-8$ & 20 & 90.0 & 90.0 & $(\mathrm{AxJAB}) 4-41$ & 20 & 80.0 & 100.0 \\
\hline$(\mathrm{AxJAB}) 4-9$ & 20 & 100.0 & 100.0 & $(\mathrm{AxJAB}) 4-42$ & 20 & 100.0 & 100.0 \\
\hline$(\mathrm{AxJ} A B) 4-10$ & 20 & 100.0 & 100.0 & $(\mathrm{AxJAB}) 4-43$ & 20 & 75.0 & 100.0 \\
\hline$(\mathrm{AxJAB}) 4-12$ & 20 & 100.0 & 100.0 & $(\mathrm{AxJAB}) 4-44$ & 20 & 90.0 & 100.0 \\
\hline$(\mathrm{AxJAB}) 4-13$ & 20 & 100.0 & 100.0 & $(\mathrm{AxJAB}) 4-45$ & 20 & 80.0 & 100.0 \\
\hline$(\mathrm{AxJAB}) 4-14$ & 20 & 100.0 & 100.0 & $(\mathrm{AxJAB}) 4-46$ & 20 & 0.0 & 100.0 \\
\hline$(\mathrm{AxJ} A B) 4-15$ & 20 & 0.0 & 100.0 & $(\mathrm{AxJAB}) 4-47$ & 20 & 0.0 & 100.0 \\
\hline$(\mathrm{AxJ} A B)$ 4-16 & 20 & 100.0 & 100.0 & $(\mathrm{AxJAB}) 4-48$ & 20 & 50.0 & 100.0 \\
\hline$(\mathrm{AxJ} A B) 4-17$ & 20 & 100.0 & 100.0 & $(\mathrm{AxJAB})$ 4-49 & 20 & 80.0 & 100.0 \\
\hline$(\mathrm{AxJ} A B) 4-18$ & 20 & 100.0 & 100.0 & $(\mathrm{AxJAB}) 4-50$ & 20 & 50.0 & 100.0 \\
\hline$(\mathrm{AxJAB})$ 4-19 & 20 & 100.0 & 100.0 & $(\mathrm{AxJAB}) 4-51$ & 20 & 50.0 & 100.0 \\
\hline$(\mathrm{AxJ} A B) 4-20$ & 20 & 0.0 & 100.0 & $(\mathrm{AxJ} A B) 4-52$ & 20 & 37.5 & 100.0 \\
\hline$(\mathrm{AxJAB}) 4-21$ & 20 & 0.0 & 100.0 & $(\mathrm{AxJAB}) 4-53$ & 20 & 100.0 & 100.0 \\
\hline$(\mathrm{AxJAB}) 4-22$ & 20 & 25.0 & 95.0 & $(\mathrm{AxJAB}) 4-54$ & 20 & 100.0 & 100.0 \\
\hline$(\mathrm{AxJAB}) 4-23$ & 20 & 0.0 & 95.0 & $(\mathrm{AxJAB}) 4-55$ & 20 & 75.0 & 100.0 \\
\hline$(\mathrm{AxJ} A B) 4-24$ & 20 & 0.0 & 95.0 & $(\mathrm{AxJAB}) 4-56$ & 20 & 77.5 & 100.0 \\
\hline$(\mathrm{AxJ} A B) 4-25$ & 20 & 0.0 & 100.0 & $(\mathrm{AxJAB}) 4-57$ & 20 & 100.0 & 100.0 \\
\hline$(\mathrm{AxJ} A B) 4-26$ & 20 & 42.5 & 100.0 & $(\mathrm{AxJAB}) 4-58$ & 20 & 100.0 & 100.0 \\
\hline$(\mathrm{AxJAB}) 4-27$ & 20 & 0.0 & 100.0 & $(\mathrm{AxJAB}) 4-59$ & 20 & 100.0 & 100.0 \\
\hline$(\mathrm{AxJ} A B) 4-28$ & 20 & 80.0 & 97.5 & $(\mathrm{AxJAB}) 4-60$ & 20 & 100.0 & 100.0 \\
\hline$(\mathrm{AxJAB})$ 4-29 & 20 & 75.0 & 100.0 & $(\mathrm{AxJAB}) 4-61$ & 20 & 100.0 & 100.0 \\
\hline
\end{tabular}

* Resistant $=100 \%$ of seedlings without necrotic spots and without sporulation (Resistentes $=100 \%$ das plântulas sem pontos necróticos e sem esporulação); (A x JAB) = Argeles x JAB 4-13-7.

The cross between parentals was held in the morning, but first the styli of the flower of the female parent were washed, before the bifurcation, to avoid self-pollination, and afterwards the artificial hybridization with flowers collected from male parents was performed.
The sowing for the $\mathrm{F}_{1}$ generation, as well as the transplant and the conduction of this generation occurred the same way as described previously. The sowing was performed on 12/1/09 and the transplant on $01 / 06 / 10$.

All the plants of $F_{1}$ generation were self pollinated and the seeds gave rise the $\mathrm{F}_{2}$ generation. These seeds were sown on $05 / 06 / 10$ and transplanted on $06 / 07 / 10$, the same way as described previously for the parentals. In $\mathrm{F}_{2}$ generation, the selection of the best plants was performed, and only the ones which present light-green color leaves, highly crispy, large size, and absence of 
side shoots and tolerant to early bolting and tip burn were kept. After the self pollination of the selected plants of $\mathrm{F}_{2}$ generation, the seeds were used to give rise to a new generation, named $\mathrm{F}_{3}(\mathrm{AxJAB})$.

In order to select resistant progenies, 20 seeds of each progeny of $\mathrm{F}_{3}$ generation were sown separately in plastic boxes $(11 \times 11 \times 3.5 \mathrm{~cm})$, lined with moistened germitex paper, for 15 days in a incubation chamber type BOD (Biochemical Oxygen Demand) at the temperature of $13^{\circ} \mathrm{C}$ and photoperiod of $12 \mathrm{~h}$. As susceptibility standard, the differentiating lettuce 'Green Tower' was used.

Due to the total control of the experimental conditions and space limitation, non-experimental design was used. However, in order to ensure that all the selected plants would be $100 \%$ resistant, the inoculation test and evaluation of the progenies were repeated four times.

The progenies were inoculated according to technique Ilott et al. (1987), using washed sporangia, of infested host tissues, shaken in distilled water. The suspension used for all races was $5 \times 10^{4}$ sporangia $\mathrm{mL}^{-1}$ (obtained by counting in a Neubauer chamber) and it consisted of a mixture of all isolates collected in the years of 2008-2010, which contained sporangia of races SPB1:01, SPB1:02, SPB1:03, SPB1:04, SPB1:05, SPB1:06 and SPB1:07. The suspension was sprayed on lettuce seedlings to the point of runoff.

After inoculation, the boxes were replaced in the $\mathrm{BOD}$ incubation chamber at $13^{\circ} \mathrm{C}$, considering that during the first six hours, they were kept in a dark chamber and, afterwards, the photoperiod was set to 12 hours.

Monitoring occurred daily and, when the first sporulation in the susceptible cultivar 'Green Tower' showed up, which typically ranged from 12 to 15 days, the progenies were evaluated individually, verifying the presence or absence of sporulation and necrotic spots, according to the methodology proposed by Van Ettekoven \& Van Der Arend (1999), discarding those that presented necrotic points and/ or sporulation of $B$. lactucae. The progenies considered resistant were the only ones which presented $100 \%$ of the seedlings without necrotic spots and without sporulation, identified, thereby, for further continuation of the breeding program.

\section{RESULTS AND DISCUSSION}

The authors observed that after the resistance test, from the 69 progenies of $\mathrm{F}_{3}$ generation, with good agronomic characteristics (light green coloration, high crispy leaves, large size plants, lack of side shoots and good tolerance to early bolting and to tip burn), only 19 presented resistance to downy mildew (Table 1). These progenies are: (AxJAB) 3-2, (AxJAB) 3-4, (AxJAB) 4-9, (AxJAB) 4-10, (АxJAB) 4-12, (AxJAB) 4-13, (AxJAB) 4-14, (AxJAB) 4-16, (AxJAB) 4-17, (AxJAB) 4-18, (AxJAB) 4-19, (AxJAB) 4-42, (AxJAB) 4-53, (AxJAB) 4-54, (AxJAB) 4-57, (AxJAB) 4-58, (AxJAB) 4-59, (AxJAB) 4-60 and (AxJAB) 4-61.

Because the resistance of the gene DM or factor R-18 is controlled by a single dominant allele (Crute \& Lebeda, 1981), in a gene-to-gene relationship, the transfer of resistance factor R-38 from Argeles strain to JAB 4-13-7 strain, although laborious and time consuming, was relatively simple, presenting high percentage of reliability.

In studies carried out by Pissardi et al. (2006), the authors verified that the 21 marketable cultivars evaluated, for resistance to race $\mathrm{SPB1}: 01$, only five, that means, approximately $23 \%$ (Locarno-crisp lettuce; Leticia-leafloose lettuce and; Raider Plus, Kasan and Rubette-head lettuce) did not allow sporulation of the pathogen in their seedlings, this way they were considered resistant to the race studied. These data helped the present work, in which the total of progenies obtained, about $27 \%$ were resistant.

Araújo et al. (2009), evaluating ten lettuce genotypes (Colorado-crisp lettuce, Raider Plus-head lettuce, Verônica-crisp lettuce, Rubete-head lettuce, Elisa-leafloose lettuce, Salinas 88-head lettuce, Grand Rapids-head lettuce, Regina 71-leafloose lettuce, Hortência-crisp lettuce and AFX-020A06-leafloose lettuce) for resistance to $B$. lactucae, verified that only three genotypes showed more than $85 \%$ of healthy seedlings (Raider Plus, Rubete and Colorado) similar to the results obtained by Pissardi et al. (2006). According to the results presented by the two authors, the need to obtain crisp type lettuce cultivars, with resistance to downy mildew, is evident, which highlights the results obtained in this study, in which 19 resistant progenies were obtained.

Yuri et al. (2004), aiming to evaluate the performance of 42 genotypes of head lettuce in the winter, in relation to the productivity and sanity of materials to $B$. lactucae, verified that among all the genotypes evaluated, only 15 presented a good option of choice by the producers during the winter, because the others showed some kind of lesion or sporulation arising from the infection by the pathogen. Although the authors have found considerable amount of effective plants for planting in winter $(35 \%)$, it is not possible to consider that these genotypes present resistance to all races of $B$. lactucae, because all the races tested were not apparent in that text. Moreover, new strains of pathogenicity with different virulence characteristics may show up, according to Souza et al. (2011) and Castoldi et al. (2012), which may break the resistance of resistant cultivars. This highlights even more the importance of obtaining progenies with genes or factors that affect resistance to $B$. lactucae, according to the results obtained in the research, aiming the establishment of breeding programs focusing on the issues addressed and, consequently, obtaining superior lines.

One of the only cultivars resistant to B. lactucae in Brazil is 'Piraroxa', which, according to Sala \& Costa (2005), is resistant to $B$. lactucae prevalent in Brazil. However, these authors do not mention which race is that and, besides, the cultivar cited has deep red color leaves, which despite being an important segment of lettuce in the country, still has little expression of cultivation and consumption in the country over the past decades, according 
to Sala \& Costa (2012). Thus, no reports of the existence of crisp lettuce cultivars, with leaves of green color, resistant to all races of $B$. lactucae identified so far in the state of São Paulo, are found. However, it is urgent and necessary to obtain cultivars for this segment, since one of the major changes in the Brazilian lettuce crop in recent decades was the adoption of crisp type lettuce 'Grand Rapids' to the detriment to the traditional looseleaf cultivar. The change from the looseleaf lettuce, type Regina, for the crisp type occurred both by the lettuce producer market as well by the consumer (Sala \& Costa, 2012).

As shown by the results presented, it is possible to conclude that 19 progenies selected in $\mathrm{F}_{3}$ for resistance to downy mildew showed potential to be advanced by the breeding program of UNESPFCAV and possibly released as cultivars resistant to races of Bremia lactucae SPB1:01, SPB1:02, SPB1:03, SPB1:04, SPB1:05, SPB1:06 and SPB1:07.

\section{ACKNOWLEDGEMENTS}

The authors thank to FAPESP (Fundação de Amparo e Pesquisa do estado de São Paulo), for financial assistance to Regular Research, case $\mathrm{n}^{\circ}$ 2008/55767-6; and CNPq (Conselho Nacional de Desenvolvimento Científico e Tecnológico) by scholarship granted to the first author.

\section{REFERENCES}

ARAÚJO JC; GOMES LAA; FIORINI CVA. 2009. Avaliação da reação de resistência a Bremia lactucae de genótipos de alface em ambiente controlado. In: CONGRESSO BRASILEIRO DE MELHORAMENTO DE PLANTAS, 5. Resumos... Guarapari: CBAB (CD-ROM).

BEHARAV A; LEWINSOHN D; LEBEDA A;
NEVO E. 2006. New wild Lactuca genetic resources with resistance against Bremia lactucae. Genetic Resources and Crop Evolution 53: 467-474.

BONNIER FJM; REININK K; GROENWOLD R. 1994. Genetic analysis of Lactuca accessions with new major gene resistance to lettuce downy mildew. Phytopathology 84: 462-468

BUENO LCS; MENDES NAG; CARVALHO SP. 2001. Melhoramento genético de plantas: princípios e procedimento. Lavras: UFLA. 282p.

CASTOLDI R; CHARLO HCO; DALPIAN T; MELO DM; BOTELHO AP; BRAZ LT. 2012. Identification of new Bremia lactucae races in lettuce in São Paulo state. Horticultura Brasileira 30: 209-213.

COSTA CP; SILVA N DA; SALA FC; BLAT SF. 2003. Patótipo de míldio de ocorrência no Brasil. IN: CONGRESSO BRASILEIRO DE OLERICULTURA, 21. Resumos... Recife: SOB (CD-ROM).

CRUTE IR; LEBEDA A. 1981. Evidence for a race-specific resistance factor in some lettuce (Lactuca sativa L.) cultivars previously considered to be universally susceptible to Bremia lactucae Regel. Theoretical and Applied Genetics 60: 185-189.

HORTEC. 2011, 15 de março. Alface Hortência. Disponível em http://www.hortec.com.br/ alface-hortencial.htm.

ILOTT TW; DURGN ME; MICHELMORE RW. 1987. Genetics of virulence in California populations of Bremia lactucae (Lettuce Downy Mildew). Phytopathology 77: 13811386.

LEBEDA A; PINK DAC; MIESLEROVA B. 2001. Host-parasite specificity and defense variability in the Lactuca spp. - Bremia lactucae pathosystem. Journal of Plant Pathology 83: 25-35.

LIMA GSA; ASSUNÇÃO IP; VALLE LAC. 2005. Controle genético de doenças radiculares. IN: MICHEREFF SJ; ANDRADE DEGT; MENEZES M. (eds). Ecologia e manejo de patógenos radiculares em solos tropicais. Recife: UFRPE, p. 247-278. (Imprensa Universitária).

MATIELLO RR; BARBIERI RL; FERNANDO IFC. 1997. Resistência das plantas a moléstias fúngicas. Ciência Rural 27: 161-168.

MENEZES NL; SANTOS OS; SCHMIDT D. 2001. Lettuce seed production in hydroponic system. Ciência Rural 31: 705-706.

PISSARDI MA; DALPIAN T; BRAZ LT. 2006. Caracterização de cultivares de alface quanto à resistência à Bremia lactucae. In: CONGRESSO BRASILEIRO DE OLERICULTURA, 46. Anais... Goiânia: ABH. p. 1168-1170.

PLANTUM NL. 2010, 6 de novembro. New race of Bremia lactucae Bl: 27 identified and nominated. Disponível em http://www. plantum.n/plantum/persberichten/10-05-03. pdf.

SALA FC. 2011. Melhoramento genético de alface. In: CONGRESSO BRASILEIRO DE OLERICULTURA, 51. Anais... Viçosa: ABH. p. S5813-S5827.

SALA FC; COSTA CP. 2005. 'Piraroxa': cultivar de alface crespa de cor vermelha intensa. Horticultura Brasileira 23: 158-159.

SALA FC; COSTA CP. 2012. Retrospectiva e tendência da alfacicultura brasileira. Horticultura Brasileira 30: 187-194.

SOUZA JO; DALPIAN T; BRAZ LT; CAMARGO M. 2011. Novas raças de Bremia lactucae, agente causador do míldio da alface, identificadas no estado de São Paulo. Horticultura Brasileira 29: 282-286.

SU H; VAN BRUGGEN AHC; SUBBARAO KV; SCHERM H. 2004. Sporulation of Bremia lactucae affected by temperature, relative humidity, and wind in controlled conditions. Phytopathology 94: 396-401.

TRANI PE; PASSOS FA; AZEVEDO FILHO JA. 1997. Alface, almeirão, chicória, escarola, rúcula e agrião d'água. In: RAIJ BV; CANTARELLA H; QUAGGIO JA; FURLANI AMC (eds). Recomendações da adubação e calagem para o Estado de São Paulo. 2. ed. Campinas: Editora IAC, p. 168169. (Boletim Técnico, 100).

VAN ETTEKOVEN K; VAN DER AREND A. 1999. Identification and denomination of "new" races of Bremia lactucae. Proceedings of the Eucarpia Meeting on leafy vegetables genetics and breeding. Olomuc, Czech Republic, p. 105-107.

VIEIRA BS; BARRETO RW. 2006. First Record of Bremia lactucae infecting Sonchus oleraceus and Sonchus asper in Brazil and its infectivity to lettuce. Journal of Phytopathology 154: 84-87.

YURI JE; RESENDE GM; MOTA JH; SOUZA RJ; RODRIGUES JÚNIOR JC. 2004. Comportamento de cultivares e linhagens de alface americana em Santana da Vargem (MG), nas condições de inverno. Horticultura Brasileira 22: 322-325. 